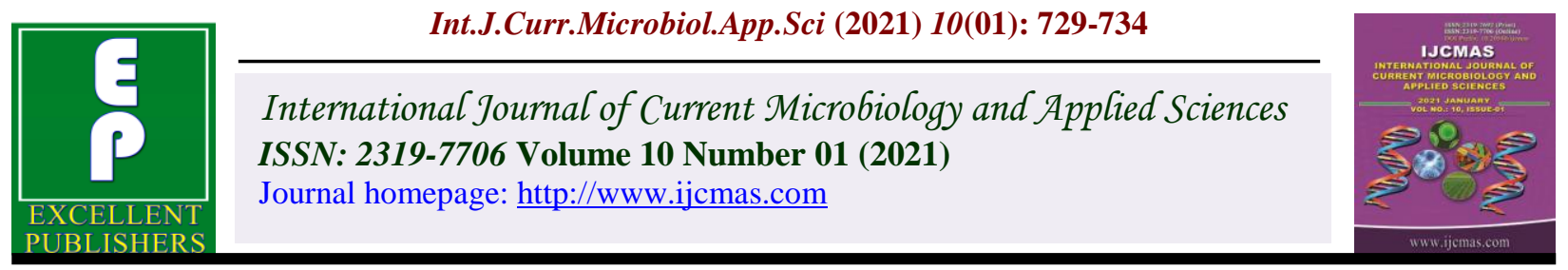

Original Research Article

https://doi.org/10.20546/ijcmas.2021.1001.089

\title{
Application of Sen's Multi-Objective Programming (MOP) for Vegetable Based Cropping Plan in Eastern Uttar Pradesh
}

\author{
Ajay Kumar Srivastava*, Rakesh Singh and O. P. Singh \\ Department of Agricultural Economics, Institute of Agricultural Sciences, \\ Banaras Hindu University, Varanasi, India \\ *Corresponding author
}

A B S T R A C T

\section{Keywords \\ Linear Programing, Sen's Multi- Objective \\ Programming (MOP), Cropping Plan, Eastern Uttar Pradesh \\ Article Info \\ Accepted: \\ 08 December 2020 Available Online: 10 January 2021}

\section{Introduction}

Indian agriculture is now dominated by horticultural production. Total horticultural production of 315 million tons is greater than 297 million tons of food grain production. Indian farmers are producing 190 million tons of vegetables and small and marginal farmers are the main contributors to vegetable production. For exploring the possibilities of increasing income and employment with lesser irrigation, the optimization of limited resources for developing a suitable cropping plan seems to be essential. Optimization techniques like applied math, wise choice of best allocation of land and water to attain maximum returns by increasing production per unit area, and per drop of water (Gadge et al., 2014). It is a technique of high importance with profit-maximizing and costminimization through a combination of farm enterprises that is possible to carry out with the given farm constraints. The optimized farm plan may assist the farmer to improve efficiency in a dynamic economic and technological atmosphere along with increasing food 
security (Otoo et al., 2015). This paper is drawn out of the Ph.D. thesis entitled, Possibilities of Increasing Farmers' Income through Production and Marketing of HighValue Horticultural Crops in Varanasi District of Eastern Uttar Pradesh of the first author submitted to the Department of Agricultural Economics, Institute of Agricultural Sciences, Banaras Hindu University, Varanasi, in 2020

Within the agriculture sector, in-depth studies have been done on the application of applied math techniques for the allocation of restricted resources (Igwe et al., 2011; Majeke, 2013; Bamiro et al., 2015). This can be done through the development of linear programming models for maximization of profit and minimization of cost thus ensuring profits to be on the higher side. Of the various techniques available in the literature, the application of Multi-Objective Programming (MOP) is pivotal for optimum resource allocation.

The objective of this study was to develop an appropriate cropping plan for increasing income and employment with lesser irrigation. This has necessitated the use of Sen's MOP model (1983) for achieving the desired goals. The optimized cropping plan developed using Sen's MOP technique has increased farm income and employment with lesser irrigation. The paper consists of four sections, an introduction followed by data and methodology describing the collection and analysis of data, results, and discussion giving the details of results obtained and inferences drawn and last section of conclusion followed by references.

\section{Materials and Methods}

Uttar Pradesh is the largest state of India with the highest population (220.7 million) and the fourth largest in space (24.1 Mha). Agriculture forms an integral part of the state's economy and also the state is popularly called the storage or bread-basket of Asian country i.e. India. Given its giant size, varied geography, climate, and topography, the state has been divided into four regions, specifically Western, Central, Eastern, and Bundelkhand. The Eastern region having 29 districts covers 35 percent of the total geographical of the state. The typical traditional annual precipitation in the region is 1025 millimeters to 1214 millimeters. Linear unit and also the atmospheric condition square measure damp sub wet to dry subhumid.

The most soil sorts found within the region square measure sandy soil, loam, calcareous, clayey deep deposit, light-weight deposit chalky clay, sandy soil, red yellow clay. Despite smart average annual precipitation, 40percent of the land is rain-fed and 60 percent is irrigated. The farming is dominated by the marginal farmers $(87 \%)$ with the average holding size less than 2 ha.

The study relies on the first information on cropping patterns, input use, and yields of major vegetable crops. For the study,10 vegetables and major cereal and pulse crops are grown by the sample farmers have been selected. The information about various expenses incurred in the cultivation of the selected crops by the sample farmers in eastern Uttar Pradesh has been collected.

\section{Analytical tools}

\section{Sen's Multi-Objective Programming Model}

The main aim of the present study to formulate a suitable cropping plan for increasing income and employment with lesser irrigation on an average farm in Eastern Uttar Pradesh. Therefore, the following three objectives have been formulated as described below: 
Maximization of farm income

Maximize $Z 1=\sum_{j=j}^{n} C_{j} X j$

Subject to the constraints,

$\sum_{j=1}^{n}$ aij Xj $\leq$ bi

$$
(\mathrm{i}=1,2,3,
$$

$\mathrm{X}_{\mathrm{j}} \geq 0 \quad(\mathrm{j}=1,2,3$

Where,

$\mathrm{Z}_{1}=$ Income (returns over variable costs)

$\mathrm{C} j=$ net returns from $\mathrm{j}^{\text {th }}$ activity

$X_{j}=$ level of $j^{\text {th }}$ activity $(I=1,2,3 \ldots . m)$

$a_{i j}=$ the number of $i^{\text {th }}$ resources required by one unit of $\mathrm{j}^{\text {th }}$ activity

$b_{i}=$ quantity available of the $i^{\text {th }}$ resource

\section{Maximization of employment}

Maximize $Z 2=\sum_{j=j}^{n} E j X j$

Subject to the constraints,

$\sum_{j=1}^{n}$ aij $\mathrm{Xj} \leq$ bi

$$
(\mathrm{i}=1,2,3 \text {, }
$$

$X_{j} \geq 0 \quad(j=1,2,3$

Where,

$\mathrm{Z}_{2}=$ Employment in mandays

$E j=$ Labourman-days required per unit of $j^{\text {th }}$ activity

$\mathrm{X}_{\mathrm{j}}=$ level of $\mathrm{j}^{\text {th }}$ activity $(\mathrm{I}=1,2,3 \ldots \mathrm{m})$

$\mathrm{a}_{\mathrm{ij}}=$ the number of $\mathrm{i}^{\text {th }}$ resources required by one unit of $j^{\text {th }}$ activity

$b_{i}=$ quantity available of the $i^{\text {th }}$ resource

\section{Minimization of irrigation water use}

Maximize $Z 3=\sum_{j=j}^{n} W_{j} X_{j}$

Subject to the constraints,

$\sum_{j=1}^{n}$ aij $\mathrm{Xj} \leq$ bi

$(\mathrm{i}=1,2,3$,

$\mathrm{X}_{\mathrm{j}} \geq 0 \quad(\mathrm{j}=1,2,3, \ldots \ldots \ldots \ldots \ldots \mathrm{n})$

Where,

$\mathrm{Z}_{3}=$ Water used in irrigation (Million cubic meters)

$\mathrm{Wj}=$ Irrigation water(million cubic meters) used by $j^{\text {th }}$ crop

$X_{j}=$ level of $j^{\text {th }}$ activity $(I=1,2,3 \ldots . m)$

$a_{i j}=$ the number of $i^{\text {th }}$ resources required by one unit of $j^{\text {th }}$ activity

$b_{i}=$ quantity available of the $i^{\text {th }}$ resource

All three objective functions have been achieved using a simple linear programming technique. The individual optimization has achieved one objective only ignoring the other two objectives. The conflicts amongst objectives have been observed. Therefore, Sen's MOP has been used for achieving all three objectives simultaneously.

Sen's MOP model is explained as below:

$Z^{*}=\frac{\sum_{j=1}^{n} C_{j} X_{j}}{Z_{1}}+\frac{\sum_{j=1}^{n} E_{j} X_{j}}{Z_{2}}-\frac{\sum_{j=1}^{n} W_{j} X_{j}}{Z_{3}}$

Subject to the constraints,

$\sum_{j=1}^{n} a_{i j} x_{j} \geq,=, \leq b_{i}$

$x_{j} \geq 0 \quad \mathrm{i}=1,2 \ldots \mathrm{mj}=1,2 \ldots \mathrm{n}$ 
Where, $\mathrm{Z}^{*}=$ Multi Objective Function

$\mathrm{Z}_{1}=$ Maximum income in income maximization (I)

$\mathrm{Z}_{2}=$ Maximum employment in employment maximization $(\mathrm{E})$

$\mathrm{Z}_{3}=$ Minimum water use in water use minimization $(\mathrm{W})$

All the major vegetable crops grown in eastern Uttar Pradesh have been considered in the optimization plan.

\section{Results and Discussion}

All three objectives have been achieved individually to verify the presence of conflicts amongst objectives. Results of individual optimization are presented in table.1. The maximization of income has increased income by 73.35 percent over the existing level of income. The employment has also increased by 19.73 percent but the use of irrigation water has increased which is not desirable. The employment maximization has increased employment by 24.82 percent and income by
66.67 with increased irrigation water use by 7.29 percent over the existing level. The minimization of irrigation water use has reduced the requirement water use by 12.49 with the increase in the income and employment by 44.88 and 3.33 percent respectively over the existing levels. The above results indicate the conflicts amongst the objectives of maximization of income and employment with minimum use of irrigation water use. However, the Sen's MOP has increased Income by 68.79 percent, employment by 22.96 percent, and reduced the use of irrigation water by 7.81 percent over the existing level. The Sen's MOP has optimized all the three objectives simultaneously.

The cropping plan generated by Sen's MOP model has been recommended for Eastern Uttar Pradesh. The existing and optimal cropping plans are presented in the table.2. The above table reveals that of the Gross cropped area of 1.94 ha. Wheat has the highest area under cultivation (0.68) in the existing cropping plan in Eastern U.P., which has declined to 0.53 ha in the optimal cropping plan.

Table.1 Individual and Multi-Objective Optimization

\begin{tabular}{|c|c|c|c|c|c|}
\hline \multirow{2}{*}{ Item } & Existing & \multicolumn{3}{|c|}{ Individual Optimization } & Sen's MOP \\
\cline { 3 - 5 } & & Max. $\mathbf{Z}_{1}$ & Max. $\mathbf{Z}_{2}$ & Min. $\mathbf{Z}_{3}$ & \\
\hline $\mathbf{Z}_{\mathbf{1}}$ & 239318 & 414873 & 398861 & 346727 & 403937 \\
(Income in Rs.) & & $(73.35)$ & $(66.67)$ & $(44.88)$ & $(68.79)$ \\
\hline $\mathbf{Z}_{\mathbf{2}}$ & 270 & 323 & 337 & 279 & 332 \\
(Employment in Days) & & $(19.63)$ & $(24.82)$ & $(3.33)$ & $(22.96)$ \\
\hline $\begin{array}{c}\mathbf{Z}_{\mathbf{3}} \\
\text { (Water Use)Million cubic } \\
\text { meters }\end{array}$ & 6046 & 6506 & 6487 & 5291 & 5574 \\
\hline
\end{tabular}

Figures in parenthesis show the percentage increase/decrease over the existing level 
Table.2 Existing and Optimal Cropping Plan

\begin{tabular}{|c|c|c|c|}
\hline Crop & Code & $\begin{array}{c}\text { Existing } \\
\text { Cropping Plan }\end{array}$ & $\begin{array}{c}\text { Optimal } \\
\text { Cropping Plan }\end{array}$ \\
\hline KharifRice & $\mathrm{X}_{1}$ & 0.684 & 0.539 \\
\hline Maize & $\mathrm{X}_{2}$ & 0.061 & 0.054 \\
\hline Jowar & $\mathrm{X}_{3}$ & 0.04 & 0.03 \\
\hline Bajra & $\mathrm{X}_{4}$ & 0.049 & 0.039 \\
\hline Sugarcane & $\mathrm{X}_{5}$ & 0.044 & 0.034 \\
\hline Brinjal & $\mathrm{X}_{6}$ & 0.094 & 0.276 \\
\hline Rabi Cauliflower & $\mathrm{X}_{7}$ & 0.038 & 0.03 \\
\hline Cabbage & $\mathrm{X}_{8}$ & 0.042 & 0.031 \\
\hline Capsicum & $\mathrm{X}_{9}$ & 0.036 & 0.031 \\
\hline Gram & $\mathrm{X}_{10}$ & 0.013 & 0.0101 \\
\hline Pea & $\mathrm{X}_{11}$ & 0.019 & 0.0181 \\
\hline Potato & $\mathrm{X}_{12}$ & 0.023 & 0.01979 \\
\hline Wheat & $\mathrm{X}_{13}$ & 0.68 & 0.53 \\
\hline Mustard & $\mathrm{X}_{14}$ & 0.0132 & 0.0104 \\
\hline Sugarcane & $\mathrm{X}_{15}$ & 0.044 & 0.034 \\
\hline Barley & $\mathrm{X}_{16}$ & 0.007 & 0.0132 \\
\hline Chilli & $\mathrm{X}_{17}$ & 0.029 & 0.0191 \\
\hline Tomato & $\mathrm{X}_{18}$ & 0.03 & 0.22 \\
\hline Onion & $\mathrm{X}_{19}$ & 0.0028 & 0.003 \\
\hline Garlic & $\mathrm{X}_{20}$ & 0.00088 & 0.00088 \\
\hline Gross cropped Area & & $\mathbf{1 . 9 4}$ & $\mathbf{1 . 9 4}$ \\
\hline & & & \\
\hline
\end{tabular}

Rice has the second-highest percent area under cultivation of about 0.684 ha in the existing cropping plan but declined to 0.539 ha in the optimized cropping plan. In Kharif season, all crops have observed a decline in their area in cultivation from existing one to optimized one, except for brinjal, which has observed the increasein area under cultivation from 0.094 ha in the existing to 0.276 ha in optimized cropping plan. In Rabi season, a similar pattern has been observed where the area under cultivation has decreased from the existing cropping plan to the optimized cropping plan, except for tomato. The area under cultivation in the tomato has significantly increased from 0.03 ha in the existing to 0.22 ha. In the optimal cropping plan.
In conclusions and Policy implication the study has attempted to develop an optimal cropping plan for enhancing farm income and employment with lesser use of irrigation water using Sen's Multi-Objective Programming (MOP) model. The cropping plan obtained using Sen's MOP has been found suitable for improving the economy of the farming community of the study area.

Based on the results the following recommendations are made:

Cultivation of water-intensive crops (Cauliflower, Cabbage, Capsicum, and chili) should be restricted for judicious use of irrigation water.

The Government should encourage crop diversification (by including less 
water-demanding crops) in the region for efficient and sustainable use of groundwater resources and improving the agricultural economy of the region.

\section{References}

Bamiro, O.M. Adedeji, I.O., Otunnaiya, A.O., Soluade, W., and Ogunjobi, J.O. (2015). Enterprise combination in the livestock sector in Southwestern, Nigeria. Journal of World Economic Research, 4(2): 38-44.

Gadge, S.B., Gorantiwar, S.D., Kumar V., and Kothari, M. (2014).linear programming approach for allocation of land and water resources in the canal command area under the surface method of irrigation- A case study. International Journal of Innovative Research in Science Engineering and Technology, 3(4): 153-160.

Igwe, K.C., Onyenweaku, C.E., and Nwaru, J.C. (2011). Application of linear programming to semi-commercial arable and fishery enterprises in Abia State, Nigeria. International Journal of Economics and Management Sciences, 1(1):75-81.
Kumari, M., Singh, O. P., and Meena, D. C. (2017). Optimizing Cropping Pattern in Eastern Uttar Pradesh Using Sen's Multi-Objective Programming Approach. Agricultural Economics Research Review, 30(347-2018-2897), 285-295.

Majeke, F. (2013). Optimum combination of crop farm enterprises: A case study of a small-scale farm in Marondera, Zimbabwe. International Researcher, 2(1): 60-65.

Otoo, J., Ofori, K., and Amoah, F. (2015). Optimal selection of crops: A case study of small scale farms in FanteakwaDistrict, Ghana. International Journal of Scientific \&Technology Research, 4(5): 142-146.

Patel, N., Thaker, M., and Chaudhari, C. (2017). Agricultural land allocation to the Major crops through Linear Programming Model. International Journal of Science and Research, 6(4), 519-522.

Sen, C. (1983). A new approach for multiobjective rural development planning, The Indian Economic Journal, 30(4): 91-96.

\section{How to cite this article:}

Ajay Kumar Srivastava, Rakesh Singh and Singh, O. P. 2021. Application of Sen's MultiObjective Programming (MOP) for Vegetable Based Cropping Plan in Eastern Uttar Pradesh. Int.J.Curr.Microbiol.App.Sci. 10(01): 729-734. doi: https://doi.org/10.20546/ijcmas.2021.1001.089 